\title{
Orthorexia nervosa tendency among students of the department of nutrition and dietetics at a university in Istanbul
}

\author{
Betul Karakus, Seyhan Hidiroglu, Nese Keskin, Melda Karavus \\ Department of Public Health, Marmara University Faculty of Medicine, Istanbul, Turkey
}

\begin{abstract}
OBJECTIVE: The aim of this study was to determine an orthorexia nervosa scale score for and evaluate orthorexic tendency among students of nutrition and dietetics according to various sociodemographic characteristics.

METHODS: This cross-sectional study was carried out in May and June of 2016 among 208 students in the nutrition and dietetics department at a university in Istanbul. After receiving the approval of the university ethics committee, of a total of 300 students, 208 agreed to join the study. Participants completed a questionnaire related to individual characteristics and the ORTO-11 scale during a face-to-face interview. The ORTO-11 scale is a verified Turkish scoring system in which a low score indicates orthorexic tendency. The Mann-Whitney $U$ test, independent samples t-test, Kruskal-Wallis test, and analysis of variance were used to assess the data. $\mathrm{P}<0.05$ was accepted as statistically significant.
\end{abstract}

RESULTS: Orthorexic tendency was significantly higher in males $(p=0.050)$ and students who lived with their family ( $p=0.002$ ). Mean ORTHO-11 scale score did not differ significantly between groups when the participants were grouped by parameters of smoking, alcohol consumption, chronic disease status, body mass index, diet observance, or use of nutritional supplement products.

CONCLUSION: The orthorexic tendency was higher in men and in students who lived with their family. Additional assessment of individual eating habits, eating behavior, and personality characteristics would shed light on the reasons for the difference between gender groups. Qualitative studies should be carried out and possible confounding factors should be determined.

Keywords: Eating behavior disorder; food choice; orthorexia.

$\mathrm{B}^{\mathrm{c}}$ ehavioral responses associated with the act of eating, manner or mode of eating, and patterns in the act guide the definition of eating behavior [1]. Eating behavior is influenced by individual percep- tion, previous experiences, nutritional status, and social, demographic, and cultural conditions [2-4].

An eating disorder is a disease state in which disorders of eating attitude and behavior emerge as a 
result of an impaired perception of body image, and the groups at greatest risk are thought to be adolescents and young women $[1,5]$. Individuals with eating disorders experience an obsessive fear of being overweight, which increases the level of anxiety related to body image $[5,6]$.

Various forms of eating disorders have existed for a very long time; however, anorexia nervosa (AN), and bulimia nervosa have only recently been included in the Diagnostic and Statistical Manual of Mental Disorders, $4^{\text {th }}$ Edition [7].

The term orthorexia nervosa $(\mathrm{ON})$ was first defined by Steven Bratman in 1997 as a form of AN. The term was derived from the Greek words "orthos" (right, true) and orexia (appetite), and it is related to an obsession with healthy foods and nutrition $[8,9]$.

In a case of $\mathrm{ON}$, typically, the individual excessively controls each meal, and failing to observe the planned dietary regime results in self-reproach and self-hatred $[10,11]$. Orthorexic individuals pay extreme attention to eating healthy foods; they are very attentive to the contents of foods they purchase, and tend to be particular about the methods and tools used in the preparation of food $[4,12]$. Many orthorexic individuals prefer to eat raw food. Mental stress caused by obsessive dietary habits may lead these individuals to refrain from consuming many foods and result in a loss of weight, as seen in the eating disorder of $\mathrm{AN}$ [13].

Healthy modifications to lifestyle and eating play a fundamental role in the prevention of various conditions, such as cardiovascular disease, cancer, osteoporosis, hypertension, and obesity $[4,13]$. Concern about healthy nutrition is considered a psychiatric disorder when it transforms into an exaggerated effort to painstakingly comply with a healthy diet, a fixation that preoccupies the individual and creates problems in their social life [13].

Since a universal definition of $\mathrm{ON}$ has not yet been made and diagnostic criteria have not been established, the contributions of new studies to the literature are of great importance.

It has been reported in some studies that $\mathrm{ON}$ is frequently present among female dieticians and that
$\mathrm{ON}$ influences their decision to become a dietician $[4,14]$. The objective of the present study was to determine ORTO-11 scores among university students of nutrition and dietetics and to evaluate their orthorexic tendency based on sociodemographic characteristics.

\section{MATERIALS AND METHODS}

\section{Method and participants}

This cross-sectional study was conducted among undergraduate students of the department of nutrition and dietetics of a university located on the Anatolian side of Istanbul province in May and June of 2016. The ethics committee of Marmara University granted approval for the study (date: May 6, 2016) before the data collection process was initiated. Probability sampling was not performed, and an attempt was made to reach all 300 students in the department program. A total of $208(70 \%)$ students were willing to participate in the study, and the data were collected in face-toface interviews using a questionnaire that inquired about individual characteristics and the ORTO11 scale.

\section{Questionnaire}

The questionnaire was used to collect sociodemographic characteristic data: height/weight (based on self-report), smoking status of the participants, use of alcohol or nutritional supplements, if they lived with their family, presence of any chronic disease in the student or their family, degree of satisfaction with their external appearance, and whether they had been on a diet to lose weight in the last 3 months. Body mass index (BMI) of the participants was calculated and World Health Organization (WHO) classification of nutritional status was applied.

\section{ORTO-11 scale}

Donini et al. introduced the ORTO-15 scale to assess $\mathrm{ON}$ in 2005, and subsequently also performed a validation study $[14,15]$. Arusoğlu et al. narrowed the focus of the ORTO-15 scale, and created the 
Turkish ORTO-11 scale adaptation in 2006 [16]. This Likert-4 type scale contains 11 questions regarding selection, purchase, and preparation of food, as well as respondent behavior with respect to the consumption of food they evaluated as "healthy." The responses "never," "sometimes," "often," or "always" yield a score of 0 to 4 points for each question; a lower score indicates greater tendency toward $\mathrm{ON}$ [16]. The ORTO-15 scale has a cut-off point, while the ORTO-11 scale does not.

\section{Data analysis}

Quantitative data were analyzed using the MannWhitney U test, independent samples t-test, Kruskal-Wallis test, and analysis of variance. Chi-square and Fisher's exact tests were used to assess qualitative data. P $<0.05$ was accepted as the level of statistical significance.

\section{RESULTS}

The study population consisted of 208 students (female: $n=179,86 \%$; male: $n=29,24 \%$ ) who volunteered to participate in the study. An equal number of students lived with their family or in a student residence (each: $n=76 ; 36 \%$ ). Of the entire group, 164 (79\%) participants were nonsmokers, and 170 $(82 \%)$ did not consume alcohol. Most $(n=199$; $96 \%$ ) said that they did not have any chronic disease, though chronic disease was present in the family of 86 (41\%) participants. Mean BMI of the participants was $20.9 \pm 2.6 \mathrm{~kg} / \mathrm{m}^{2}$ according to the WHO classification of nutritional status, 162 (78\%) of individuals were normal weight.

In response to the question, "Are you pleased with your image in the mirror?" $62(30 \%)$ said not at all/not pleased, and 166 (70\%) said somewhat/very pleased. Most ( $n=159 ; 77 \%)$ of the participants had not been following a diet to lose weight within the last 3 months. In addition, 159 (77\%) participants were not using nutritional supplements at all, while $36(17 \%)$ participants said that they had used such products in the past. Thirteen participants were using nutritional supplements at the time of the interview. A summary of these characteristics is provided in Table 1 .
TABLE1. Distribution of participants according to characteristics

n $\%$

Gender

Female

179

Male

$29 \quad 13.9$

University class

Year 1

Year 2

Year 3

Year 4

$\begin{array}{ll}32 & 15.4\end{array}$

$75 \quad 36.1$

$\begin{array}{ll}56 & 26.9\end{array}$

Residence

With family

$45 \quad 21.6$

Student housing

$76 \quad 36.5$

Student hostel

$50 \quad 24.0$

Alone

Other

$\begin{array}{ll}76 & 36.5\end{array}$

31.4

$3 \quad 1.4$

Tobacco use

Never smoked

$\begin{array}{ll}164 & 78.8\end{array}$

Quit smoking

$17 \quad 8.2$

Current smoker

$27 \quad 13.0$

Alcohol use

Yes

38

No

18.3

Chronic disease

Present

$170 \quad 81.7$

Absent

4.3

Chronic disease in the family

Present

$199 \quad 95.7$

Absent

86

122

41.3

BMI group

$\begin{array}{lll}\text { Underweight } & 32 & 15.4\end{array}$

Normal $\quad 163 \quad 78.4$

Overweight $\quad 11 \quad 5.3$

Obese $\quad 2 \quad 1.0$

Are you pleased with your image in the mirror?

$\begin{array}{lll}\text { Not at all pleased } & 4 & 1.9\end{array}$

$\begin{array}{lll}\text { Not pleased } & 10 & 4.8\end{array}$

$\begin{array}{lll}\text { Somewhat pleased } & 48 & 23.1\end{array}$

$\begin{array}{lll}\text { Pleased } & 122 & 58.7\end{array}$

$\begin{array}{lll}\text { Very pleased } & 24 & 11.5\end{array}$

Are you on a diet?

$\begin{array}{lll}\text { Yes } & 43 & 20.7\end{array}$

$\begin{array}{lll}\text { No } & 165 & 79.3\end{array}$

Nutritional supplement use

$\begin{array}{lll}\text { Never used } & 159 & 76.4\end{array}$

Used in the past $\quad 36 \quad 17.3$

I am still using $\quad 13 \quad 6.3$

Total

$208 \quad 100.0$

BMI: Body mass index. 
TABLE2. ORTO-11 score according to characteristics

\begin{tabular}{|c|c|c|c|c|c|}
\hline & $\mathrm{n}$ & $\%$ & Mean & SD & $\mathrm{p}$ \\
\hline \multicolumn{6}{|l|}{ Gender } \\
\hline Female & 179 & 86.1 & 28.9 & 3.7 & \multirow[t]{2}{*}{0.050} \\
\hline Male & 29 & 13.9 & 27.4 & 3.4 & \\
\hline \multicolumn{6}{|l|}{ University class } \\
\hline Year 1 & 32 & 15.4 & 29.4 & 3.8 & \multirow[t]{4}{*}{0.13} \\
\hline Year 2 & 75 & 36.1 & 28.9 & 3.3 & \\
\hline Year 3 & 56 & 26.9 & 29.1 & 3.0 & \\
\hline Year 4 & 45 & 21.6 & 27.4 & 4.6 & \\
\hline \multicolumn{6}{|l|}{ Residence } \\
\hline With family & 76 & 36.5 & 27.7 & 3.8 & \multirow[t]{2}{*}{0.002} \\
\hline Other & 132 & 63.5 & 29.3 & 3.5 & \\
\hline \multicolumn{6}{|l|}{ Tobacco use } \\
\hline Smoker & 181 & 87.0 & 27.5 & 4.2 & \multirow[t]{2}{*}{0.07} \\
\hline Nonsmoker & 27 & 13.0 & 28.9 & 3.5 & \\
\hline \multicolumn{6}{|l|}{ Alcohol use } \\
\hline Yes & 38 & 18.3 & 29.5 & 3.4 & \multirow[t]{2}{*}{0.18} \\
\hline No & 170 & 81.7 & 28.5 & 3.7 & \\
\hline \multicolumn{6}{|l|}{ Chronic disease } \\
\hline Yes & 9 & 4.3 & 30.4 & 3.4 & \multirow[t]{2}{*}{0.1} \\
\hline No & 199 & 95.7 & 28.6 & 3.7 & \\
\hline \multicolumn{6}{|c|}{ Chronic disease in the family } \\
\hline Yes & 86 & 41.3 & 29.0 & 3.7 & \multirow[t]{2}{*}{0.5} \\
\hline No & 122 & 58.7 & 28.5 & 3.7 & \\
\hline \multicolumn{6}{|c|}{ Are you pleased with your image in the mirror?* } \\
\hline Low & 62 & 29.8 & 29.2 & 2.6 & \multirow[t]{2}{*}{0.4} \\
\hline High & 146 & 70.2 & 28.5 & 4.0 & \\
\hline \multicolumn{6}{|l|}{ BMI group** } \\
\hline Underweight/normal & 195 & 93.8 & 28.8 & 3.6 & \multirow[t]{2}{*}{0.38} \\
\hline Overweight/obese & 13 & 6.3 & 27.6 & 4.1 & \\
\hline \multicolumn{6}{|l|}{ On diet } \\
\hline Yes & 43 & 20.7 & 29.5 & 3.5 & \multirow[t]{2}{*}{0.15} \\
\hline No & 165 & 79.3 & 28.5 & 3.7 & \\
\hline \multicolumn{6}{|l|}{ Nutritional supplement use } \\
\hline Nonuser & 159 & 76.4 & 28.6 & 3.6 & \multirow[t]{2}{*}{0.4} \\
\hline Past/present user & 49 & 23.6 & 29.1 & 3.8 & \\
\hline
\end{tabular}

SD: Standard deviation; *Low: I am not pleased at all/I am not pleased/I am somewhat pleased; High: I am pleased/I am a very pleased. **BMI: Body mass index.

The mean ORTO-11 scale score of all participants was $16.5 \pm 4.6$ points. The distribution of ORTO-11 scores based on characteristics of the participants can be seen in Table 2. The mean ORTO11 score of male participants was significantly lower than that of female participants (Table 2).

When the participants were grouped based on smoking status, presence of chronic disease in the student or the family, and BMI, no significant difference was found in mean ORTO-11 score (Table 2). 
When the participants were divided into groups of those living with family members and another residence, examination of the ORTO-11 scores revealed that mean of those living at home (27.7) was significantly lower than the other group (29.3; $\mathrm{p}=0.002$ ) (Table 2).

The mean ORTO-11 score was 1 point higher among those who were observing a diet compared with those who didn't, but the difference was not significant $(p=0.15)$. The mean ORTO-11 score of the group who had not used nutritional supplements was 0.5 point lower than those who had previously used such products and current users, without a statistically significant difference between groups. Among the participants who were not very pleased with their image in the mirror, the mean ORTO-11 score of was 0.7 points higher than those who were very pleased, but there was no significant difference between groups $(p=0.4)$ (Table 2$)$.

\section{DISCUSSION}

The ORTO-11 scale score of students of a university department of nutrition and dietetics was calculated and analyzed based on sociodemographic data and characteristics of the respondents. The association between gender and tendency toward $\mathrm{ON}$ was examined, and it was observed that the male participants had a greater predisposition toward $\mathrm{ON}$. Some studies [17-21] have reported no significant association between gender and inclination toward ON, while in others $[22,23]$, the tendency was observed more often among men. Increased ON tendency among women has also been reported [24, 25]. Eating disorders are generally acknowledged to be more frequently seen among women [26]. However in our study, a lack of adequate data about the eating attitudes and behavior of the participants made it difficult to definitively determine the cause of this difference between gender groups. In one study conducted [25], the risk of ON was found to be 5-fold higher among individuals displaying an abnormal eating attitude compared with those with normal eating attitudes. Our subgroup analyses revealed that male participants more frequently consumed tobacco products $(p=0.005)$ and alco- hol $(p=0.021)$ compared with female respondents. Though unhealthy habits such as cigarette use were more frequently encountered in men, the greater tendency toward $\mathrm{ON}$ may be related to personality characteristics of the male participants. One of the important limitations of this study was our inability to use a standard scale to evaluate the personality characteristics of our participants. Furthermore, our study group consisted only of students of the department of nutrition and dietetics, and therefore our results may be different from those of a survey of the general population.

Study participants living with their family were found to be significantly more predisposed toward $\mathrm{ON}$ in our analysis; however previous studies did not find a significant association between living conditions and tendency toward $\mathrm{ON}[23,25]$ Subgroup analyses of our study group revealed that frequency of tobacco $(p=0.052)$ and alcohol $(p=0.003)$ use was 3 times lower in participants living with their family relative to other groups. Higher predisposition toward $\mathrm{ON}$ among individuals refraining from an unhealthy lifestyle seems to be a consistent finding. While observing healthy dietary habits should be encouraged, it becomes dangerous when it becomes an obsessive type of eating behavior. Individuals with this pathological focus will likely develop eating behavior that is not dependent on the place of residence $[4,10,13]$. Since this was a cross-sectional study, it was difficult to evaluate the causal relationship between residence environment and predisposition toward $\mathrm{ON}$.

As in previous studies [14,24], a significant association between $\mathrm{BMI}$ and $\mathrm{ON}$ was not found in our research. In the aforementioned studies, the authors indicated that BMI was not a determinative factor for $\mathrm{ON}$ and that individuals demonstrating orthorexic behavior generally had a normal BMI. Another study found a significant correlation between extraordinary focus on external appearance, fear of being overweight, and a tendency toward ON [19]. Most (93.8\%) of our study participants had a low/ normal BMI, which might have prevented us from distinguishing any such difference between groups.

When participants were grouped according to use of tobacco products and alcohol, the ORTO- 
11 scores did not differ significantly between groups. No significant association was found between the presence of a chronic disease in the individual or in the family and the participants' tendency toward $\mathrm{ON}$.

Another limitation of our study was the lack of a more detailed inquiry about eating attitude. Orthorexic trend is more frequently seen among individuals who follow a strict dietary regimen [24]. A significant correlation was not found between diet regimen, use of nutritional supplements, and tendency toward ON. This may be due to the small number of study participants who observed a diet plan or used nutritional supplement products.

\section{Conclusion and Recommendations}

In our study, the tendency toward $\mathrm{ON}$ was greater among men. Further evaluation of eating attitudes and eating behavior, as well as personality characteristics of the individuals, could add to our understanding of difference based on gender. Tendency toward $\mathrm{ON}$ was also more frequently detected in participants living with their family. Qualitative studies should be conducted to examine the association between living with family and inclination toward $\mathrm{ON}$, and potential confounding factors should be identified. The ORTO-11 scale does not have a cut-off value, which may lead us to evaluate healthy behavior patterns as a pathological condition Therefore, validation and reliability studies of this scale should be performed.

\section{Conflict of Interest: None declared.}

Financial Disclosure: The authors declared that this study has received no financial support.

Authorship contributions: Concept - S.H, M.K.; Design B.K., N.K., M.K.; Supervision - M.K., S.H.; Funding - B.K., N.K., Materials - N.K., B.K.; Data Collection and processing - N.K., B.K..; Analysis and interpretation -N.K., B.K. ; Literature search N.K., B.K., M.K., S.H.; Writing - N.K., B.K., S.H., M.K.; Critical review - M.K., S.H..

\section{REFERENCES}

1. Gonçalves Jde A, Moreira EA, Trindade EB, Fiates GM. Eating disorders in childhood and adolescence. Rev Paul Pediatr 2013;31:96-103.
2. Fairburn CG, Harrison PJ. Eating disorders. Lancet 2003;361:407-16.

3. Köster EP. Diversity in the determinants of food choice: A psychological perspective. Food Quality and Preference 2009;20:70-82.

4. Gezer C, Kabaran S. Beslenme ve diyetetik bölümü kız öğrencileri arasında görülen ortoreksiya nervosa riski. SDÜ Sağlık Bilimleri Dergisi 2013;4:14-22.

5. Özgen L, Kınac1 B, Arlı M. Eating attitudes and behaviors of adolescents. Journal of Faculty of Educational Sciences 2012;45:229-47.

6. Bellodi L, Cavallini MC, Bertelli S, Chiapparino D, Riboldi C, Smeraldi E. Morbidity risk for obsessive-compulsive spectrum disorders in first-degree relatives of patients with eating disorders. Am J Psychiatry 2001;158:563-9.

7. Andersen A, Yager J. Eating disorders. In: Sadock BJ, Sadock VA, editors. Comprehensive Textbook of Psychiatry. $8^{\text {th }}$ ed. Philadelphia: Lippincott Williams \& Wilkins; 2005. p. 2005-21.

8. Cartwright MM. Eating disorder emergencies: understanding the medical complexities of the hospitalized eating disordered patient. Crit Care Nurs Clin North Am 2004;16:515-30.

9. Mathieu J. What is orthorexia? J Am Diet Assoc 2005;105:1510 2.

10. Bratman S, Knight D. Health Food Junkies. Newyork: Broadway Books; 2000. p. 210-9.

11. Brytek-Matera A, Rogoza R, Gramaglia C, Zeppegno P. Predictors of orthorexic behaviours in patients with eating disorders: a preliminary study. BMC Psychiatry 2015;15:252.

12. Catalina Zamora ML, Bote Bonaechea B, García Sánchez F, Ríos Rial B. Orthorexia nervosa. A new eating behavior disorder? Actas Esp Psiquiatr 2005;33:66-8.

13. Aldana SG, Greenlaw RL, Diehl HA, Salberg A, Merrill RM, Ohmine $\mathrm{S}$, et al. Effects of an intensive diet and physical activity modification program on the health risks of adults. J Am Diet Assoc 2005;105:371-81.

14. Donini LM, Marsili D, Graziani MP, Imbriale M, Cannella C. Orthorexia nervosa: a preliminary study with a proposal for diagnosis and an attempt to measure the dimension of the phenomenon. Eat Weight Disord 2004;9:151-7.

15. Donini LM, Marsili D, Graziani MP, Imbriale M, Cannella C. Orthorexia nervosa: validation of a diagnosis questionnaire. Eat Weight Disord 2005;10:e28-32.

16. Arusoğlu G, Kabakçi E, Köksal G, Merdol TK. Orthorexia nervosa and adaptation of ORTO-11 into Turkish. Turk Psikiyatri Derg 2008;19:283-91.

17. Varga M, Thege BK, Dukay-Szabó S, Túry F, van Furth EF When eating healthy is not healthy: orthorexia nervosa and its measurement with the ORTO-15 in Hungary. BMC Psychiatry $2014 ; 14: 59$

18. Brytek-Matera A, Donini LM, Krupa M, Poggiogalle E, Hay P. Orthorexia nervosa and self-attitudinal aspects of body image in female and male university students. J Eat Disord 2015;3:2.

19. Barnes MA, Caltabiano ML. The interrelationship between 
orthorexia nervosa, perfectionism, body image and attachment style. Eat Weight Disord 2017;22:177-184.

20. Dunn TM, Gibbs J, Whitney N, Starosta A. Prevalence of orthorexia nervosa is less than $1 \%$ : data from a US sample. Eat Weight Disord 2017;22:185-92.

21. Aksoydan E, Camci N. Prevalence of orthorexia nervosa among Turkish performance artists. Eat Weight Disord 2009;14:33-7.

22. Fidan T, Ertekin V, Işikay S, Kirpinar I. Prevalence of orthorexia among medical students in Erzurum, Turkey. Compr Psychiatry 2010;51:49-54.

23. Özenoğlu A, Gökhan D. Üniversite Gençliğinde Yeme Bozukluğunun Yordayıcıları Olarak Benlik Saygısı ve Beslenme
Eğitiminin Ortoreksiya Nervoza Gelişmesi Üzerine Etkisi. Bozok Tip Dergisi 2015;5:5-14.

24. Arusoğlu G, Kabakçi E, Köksal G, Merdol TK. Orthorexia nervosa and adaptation of ORTO-11 into Turkish. Turk Psikiyatri Derg 2008;19:283-91.

25. Sanlier N, Yassibas E, Bilici S, Sahin G, Celik B. Does the rise in eating disorders lead to increasing risk of orthorexia nervosa? Correlations with gender, education, and body mass index. Ecol Food Nutr 2016;55:266-78.

26. Varga M, Dukay-Szabó S, Túry F, van Furth EF. Evidence and gaps in the literature on orthorexia nervosa. Eat Weight Disord 2013;18:103-11. 